\title{
Giant Submandibular Gland Duct Sialolith: A Case Report
}

\section{Dev Submandibuler Gland Kanal Tașı: Bir Olgu Sunumu}

\author{
Kamran Sarı', Caner Șahin ${ }^{2}$ \\ ${ }^{1}$ Department of Ear Nose Throat, Bozok University School of Medicine, Yozgat, Turkey; ${ }^{2}$ Ear Nose Throat Clinics, Akyazı State Hospital, \\ Sakarya, Turkey
}

\begin{abstract}
Sialolithiasis is one of the most common diseases of the salivary glands and is characterized by the obstruction of salivary gland or its duct due to the formation of calcareous plaque. The term of giant sialolith is used for the stones over 15 millimeters or $1 \mathrm{gram}$. It is rarely reported in the literature. We reported a case of a sialolith measured between 25 to $30 \mathrm{~mm}$ and located in the submandibuler gland orifice. We excised the sialolith via intraoral approach. Normal saliva flow must be performed during treatment. Minimal invasive surgery is recommended.
\end{abstract}

Key words: sialolithiasis; salivary gland diseases; submandibular gland

\section{ÖZET}

Siyalolitiazis, tükrük bezlerinin en sık karșılașılan hastalıklarından biridir. Siyalolitiazis, tükürük bezinin veya kanalının kalkareoz plak olușumuna bağı tıkanmasıyla karakterizedir. Dev sialolit tanımı 15 milimetreden büyük veya 1 gramdan ağır tașlar için kullanılmaktadır. Literatürde nadiren bildirilmiștir. Bu yazıda, boyutu 25 ile 30 milimetre arasında olan bir dev sialolit olgusu sunduk. Bizim olgumuzda sialolit submandibuler gland orifisinin girișine yerleșmiști. Sialoliti intraoral yaklașımla eksize ettik. Tedavide normal tükürük akıșı sağlanmalıdır. Cerrahi olarak minimal invaziv yaklașım önerilmektedir.

Anahtar kelimeler: sialolit; tükrük bezi hastalıkları; submandibuler bez

\section{Introduction}

Sialolithiasis is one of the most common diseases of salivary glands ${ }^{1}$. Nearly 12 of every 1000 adults are referred to physicians with complaint of sialolithiasis $^{2}$. Males are more frequently affected than females $(2 / 1)^{3}$. It is observed in submandibular duct in $80 \%$ of the cases ${ }^{4}$. and is rarely bigger than $15 \mathrm{~mm}^{1}$. In $88 \%$ percent of cases, it is smaller than $10 \mathrm{~mm}^{4}$. The term

Yard. Doç. Dr. Kamran Sar, Adnan Menderes Blv. No: 190, Yozgat, Türkiye Tel.03542127060Email.ksari77@hotmail.com

Received: 11.06.2014 - Accepted: 22.11.2014 giant sialolith is used when the sialolith is over $15 \mathrm{~mm}$ or 1 gram $^{5,6}$. Giant sialolithiasis of submandibular duct has been reported rarely ${ }^{7}$. We will discuss giant submandibular gland duct sialolithiasis in this report.

\section{Case Report}

A 55 year-old male patient complaining of intermittent pain and swelling in left submandibular area was admitted. Starting four months ago, the pain was increasing during chewing. The patient's past medical history was unremarkable.

On otolaryngologic examination, palpation revealed a swollen area corresponding to the anatomic location of submandibular salivary gland. The swollen area was palpated extra orally and intraorally, it was firm and nontender. A firm yellowish mass of approximately $4 \mathrm{~cm} \times$ $1 \mathrm{~cm}$ on the floor of the mouth was determined (Figure 1). A lateral occlusal radiograph showed a large radioopaque calculus in the floor of the mouth (Figure 2).

Ultrasound revealed a giant stone in the submandibular area. Biochemical and serological studies were unremarkable.

The calculus was excised via transoral sialolithotomy under local anesthesia (Figure 3). Amoxicillin-clavulanic acid, 1 gram twice a day, and ketoprofen twice a day were used till the post operative seventh day. The symptoms resolved following operation. There was no recurrence and complication in the sixth month of the follow up.

\section{Discussion}

Sialolithiasis occurs after the obstruction of the salivary glands or ducts ${ }^{8}$. Mechanism of the calculus formation is not understood completely, however there are some theories. 


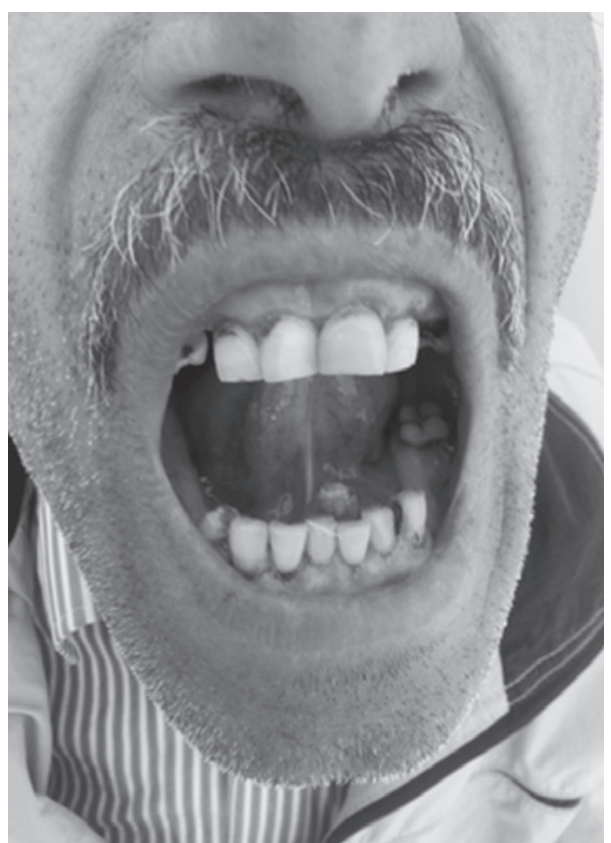

Figure 1. Sialolith protruding from the Wharton duct.

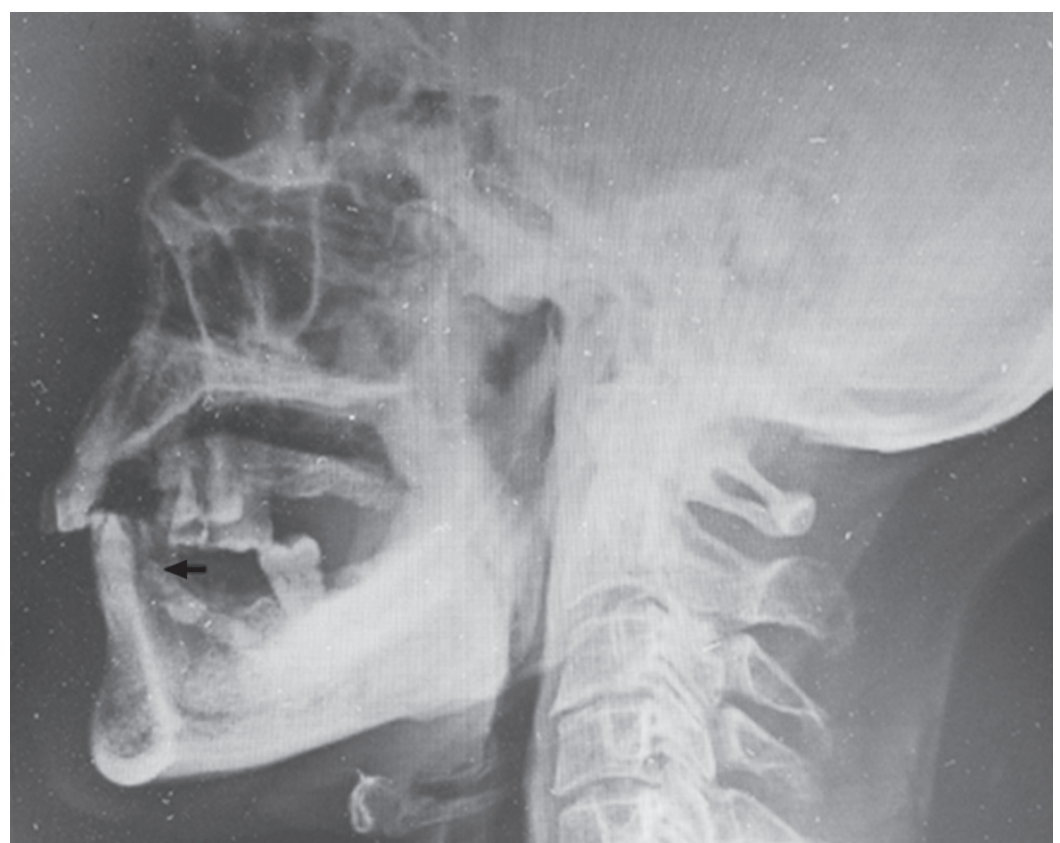

Figure 2. The opacity at the floor of the mouth is shown in lateral cervical X-Ray graphy (black arrow).

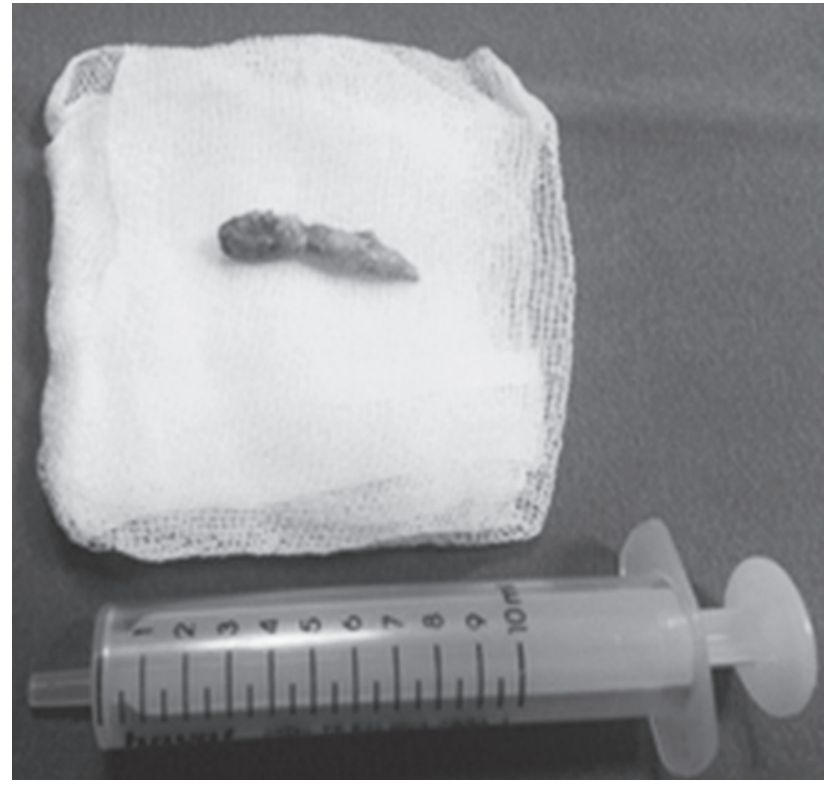

Figure 3. Sialolith following excision.

According to Harrison, micro calculus occurs in some instances, however it is excreted out of the natural ostium of the gland. Certain conditions causing changes in the chemical composition of the saliva, secondary to the partial or complete obstruction of the duct may increase the size of the calculus ${ }^{9}$. Depending on an alternative theory the mucous plaque forms a nidus and leads to the formation of calculus. The nidus increases with the accumulation of inorganic substances ${ }^{10}$.

The flow of the saliva is contrary to the gravity, thus, about $80 \%$ of sialolithiasis is encountered in submandibuler gland or duct, though the Wharton's duct is longer and wider as the Stensen's duct ${ }^{4}$.

The saliva in submandibular gland is more alkaline. Submandibular gland has mucinous secretion which is rich of protein, calcium and phosphate ${ }^{11}$. An experimental study showed that the magnesium content of the saliva secretion is the main factor for calculus formation ${ }^{12}$.

Giant sialolith is defined when it is over 1 gram or $15 \mathrm{~mm}^{5,6}$. The calculus we excised was about $25 \mathrm{~mm}$. Giant sialolithiasis usually has a dense concentration and a yellowish color. It is radio-opaque and sometimes interferes with teeth ${ }^{1}$. The symptoms include pain and swelling during eating secondary to the distension in the gland ${ }^{1}$. If the calculus dilates the duct, it does not hinder the flow of the saliva. Thus, it may become giant without any symptom ${ }^{13}$.

Standard mandibular occlusal graph is the best diagnostic option to determine the calculus in the duct ${ }^{7}$. Sialography, ultrasonography and computerized tomography may help in diagnosis ${ }^{14}$. We identified the radio-opaque calculus with the aid of the radiologic image. 
Sialolithiasis rarely may associates with salivary gland tumors. Hasegawa et al. and Batzakakis et al. reported a case associated with adenoid cystic carcinoma ${ }^{15}$, ${ }^{16}$. Sialoendoscopy is a new technique used in the diagnosis and treatment of sialolithiasis and it properly locates the stone ${ }^{17,18}$. However its use is limited in sialolithiasis over $6 \mathrm{~mm}$ and in case where the sialolithiasis is originated from the wall of duct ${ }^{18-22}$. Despite the fact, Wallace et al. excised successfully a giant submandibular gland and duct sialolith with sialoendoscopy. Sialolith was found at the gland in six cases and at the duct in one case. They could save the submandibular gland in $86 \%$ of the cases and concluded that the sialoendoscopy might be used successfully in sialolithiasis of submandibular glands and ducts ${ }^{17}$. Trans-oral sialolithotomy is usually performed for the sialolithiasis palpated easily at the floor of the mouth ${ }^{17}$.

Submandibular stones can be removed surgically by intra or extra oral approach ${ }^{17}$. The choice of the treatment depends on the stone's location. Intraoral approach is often used when the calculi is located anterior to the lingual nerve and artery. The complications of intraoral surgery are lingual nerve anesthesia and injury. The lingual nerve loops around the distal portion of Warthin's duct. Excision of the submandibular gland by an external approach carries a risk of marginal mandibulary nerve palsy in $0-8 \%$ of the cases ${ }^{17}$. Shock wave lithotripsy, basket retrieval, and endoscopic laser lithotripsy are new treatment opsions ${ }^{22}$. A review found that the retrieval of stones by baskets or micro forceps was usually performed for stones less than 5 $\mathrm{mm}$ and extracorporeal lithotripsy was mainly used for fixed parotid stones less than $7 \mathrm{~mm}$ in diameter ${ }^{23}$. We excised the calculus via transoral sialolithotomy. Normal saliva flow must be maintained during treatment. Minimal invasive surgery is the recommended surgical option.

\section{References}

1. Oteri G, Procopio RM, Cicciu M. Giant salivary gland calculi (GSGC): Report of two cases. Open Dent J 2011;5:90-5.

2. Iro H, Schneider HT, Fodra C, et al. Shockwave lithotripsy of salivary duct Stones. Lancet 1992;339:1333-6.

3. Bodner L. Giant salivary gland calculi: diagnostic imaging and surgical management. Oral Surg Oral Med Oral Pathol Oral Radiol Endod 2002;94:320-3.

4. Levy DM, Remine WH, Devine KD. Salivary gland calculi. Pain, swelling associated with eating. JAMA 1962;181:1115-9.
5. Raveenthiran V, Hayavadana Rao PV. Giant calculus in the submandibuler salivary duct: Report of the first prepubertal patient. Pediatr Surg Int 2004;20:163-4.

6. Bodner L. Giant salivary gland calculi: Diagnostic imaging and surgical management. Oral Surg Oral Med Oral Pathol Oral Radiol Endod 2002;94:320-3.

7. Gupta A, Rattan D, Gupta R. Giant sialoliths of submandibuler gland duct: Report of two cases with unusual shape. Contemp. Clin Dent 2013;4:78-80.

8. Epker BN. Osbtructive and inflamatory disease of the major salivary glands. Oral Surg Oral Med Pathol 1972;33:2-27.

9. Harrison JD. Causes, natural history and incidence of salivary stones and obstructions. Otolaryngol Clin North Am 2009; 42:927-47.

10. Marchal F, Dulgerov P. Sialolithiasis menagement: the state of the art. Arch Otolaryngol Head Neck Surg 2003;129:951-6.

11. Raksin SZ, Gould SM, William AC. Submandibuler gland sialolith of unusual size and shape. J Oral Surg 1975;33:142-5.

12. Grases F, Santiago C, Simonet BM, Costa-Bauza A. Sialolithiasis: Mechanism of calculi formation and etiologic factors. Clin Chim Acta 2003;334:131-6.

13. Manjunath R, Burman R. Giant submandibuler sialolith of remarkable size in the comma area of Wharton's Duct: A case report. J Oral Maxillofac Surg 2009;67:1329-32.

14. Lomas DJ, Carrol NR, Johnson G, et al. MR sialography. Work in progress. Radiology 1996;200:129-33.

15. Hasegawa M, Cheng J, Maruama S, et al. Complication of adenoid cystic carcinoma and sialolithiasis in the submandibuler gland: reportof a case and is etiological background. Int J Oral Maxillofac Surg 2011;40:647-50.

16. Batzakakis D, Apostolopoulos K, Bardanis I. A case report of coexistence of a sialolith and an adenoidcystic carcinoma in the carcinoma inthe submandibular gland. Med Oral Pathol Oral Cir Bucal 2006;11:286-8.

17. Wallace E, Tauzin M, Hagan J, et al. Management of gianth sialoliths: Review of the literature and preliminary experience with interventional sialendoscopy. Laryngoscope 2010;120:1974-8.

18. Katz P. New techniques for the treatment of salivarylithiasis: sialoendoscopy and extracorporal lithotripsy:1773 cases. Ann Otolaryngol Chir Cervicafac 2004;121:123-32.

19. Koch M, Zenk J, Iro H. Diagnostic and interventional sialoscopy in obstructive diseases of the salivary glands. HNO 2008;56:835-43.

20. Marchal F, Dulgerov P. Sialolithiasis management: the state of the art. Arch Otolaryngol Head Neck Surg 2003;129:951-96.

21. Marchal F, Dulgerov P, Becker M et al. Specifity of parotid sialendoscopy. Laryngoscope 2001;111:264-71.

22. Nahlieli O, Shacham R, Bar T et al. Endoscopic mechanical retrieval of sialoliths. Oral Surg Oral Med Oral Pathol Oral Radiol Endod 2003;95:396-402.

23. Iro $\mathrm{H}, \mathrm{Zenk} \mathrm{J}$, Escudier MP, et al. Outcome of minimally invasive management of salivary calculi in 4,691 patients. Laryngoscope 2009;119:263-8. 